\title{
Critical Appraisal of International Clinical Practice Guidelines in Kidney Transplantation Using the Appraisal of Guidelines for Research and
}

Education (AGREE) II Tool: A Systematic Review

Katriona Jane Marie O'Donoghue, BSc, Hons ${ }^{1}$, Rhiannon D. Reed, MPH ${ }^{2}$, Simon R. Knight, MA, MChir, FRCS ${ }^{1,3}$, John M. O’Callaghan, $\operatorname{MBBS}^{1,3}$, Anam A. Ayaz-Shah, BSc, Hons, Psychology ${ }^{1}$, Sevda Hassan, MBBS, BMedSci, Hons ${ }^{4}$, Annemarie Weissenbacher, $\mathrm{MD}^{3}$, Peter J. Morris, AC, FRS, FMedSci, FRCP, FRCS ${ }^{1,3}$, Liset H.M. Pengel, $\mathrm{PhD}^{1,3}$

${ }^{1}$ Centre for Evidence in Transplantation, Clinical Effectiveness Unit, Royal College of Surgeons of England, London, UK.

${ }^{2}$ University of Alabama at Birmingham, Comprehensive Transplant Institute, Birmingham, Alabama, USA.

${ }^{3}$ Nuffield Department of Surgical Sciences, University of Oxford John Radcliffe Hospital, Headington, Oxford, UK.

${ }^{4}$ West London Renal and Transplant Centre, Hammersmith Hospital, Imperial College Healthcare NHS Trust, London, UK.

\section{Correspondence information}

Corresponding Author: Katriona JM O'Donoghue

E-mail: kodonoghue@ rcseng.ac.uk

Mailing address: Centre for Evidence in Transplantation, Clinical Effectiveness Unit, Royal College of Surgeons, 35-43 Lincoln's Inn Fields, London WC2A 3PE. 


\section{Systematic review registration}

PROSPERO ID: CRD42015027356

\section{AUTHORSHIP PAGE}

\section{Authorship}

$\mathrm{KO}, \mathrm{RR}, \mathrm{SK}, \mathrm{JO}, \mathrm{PM}$ and LP were involved in the concept and design of the systematic review. KO and LP designed the search strategy. KO and RR screened search results for relevant full-texts and these were checked by LP. KO and RR performed the data extraction. All authors were involved in the critical appraisal of guidelines with AGREE II. KO wrote the initial drafts of the manuscript and these were revised by LP. All authors critically revised the final draft of the manuscript. KO had full access to all of the data in the study and takes responsibility for the integrity of the data and the accuracy of the data analysis. KO is guarantor.

\section{Disclosure}

All authors have completed the ICMJE uniform disclosure form at www.icmje.org/coi_disclosure.pdf and the authors declare no conflicts of interest.

\section{Funding}

No funding received 


\section{ABBREVIATIONS PAGE}

AGREE II - Appraisal of Guidelines for Research and Evaluation II

CPG - Clinical Practice Guideline

Ktx - Kidney Transplantation

NHS - National Health Service

NICE - National Institute for Health and Care Excellence

UK - United Kingdom

WHO - World Health Organization 


\section{ABSTRACT}

Background: Whilst Clinical Practice Guidelines (CPGs) are used for the development of local protocols in kidney transplantation (Ktx), the quality of their methodology is variable. This systematic review aimed to critically appraise international CPGs in all aspects of Ktx using the Appraisal of Guidelines for Research and Evaluation (AGREE) II tool. Methods: CPGs in Ktx and donation published between 2010 and 2017 were identified from MEDLINE, Embase, National Guideline Clearinghouse, NHS and NICE Evidence Searches, and the websites of transplant societies. Using AGREE II, 3 appraisers assessed the quality of CPGs. Interrater reliability was measured using the intraclass correlation coefficient (ICC). Results: Searches identified 3,168 records and 115 CPGs were included. The highest scoring AGREE II domain was 'Scope and Purpose' (80\%; Range 30-100\%), followed by 'Clarity of Presentation' (77\%; Range 43-98\%), 'Editorial independence' (52\%; Range 0-94\%), 'Rigour of Development' (47\%; Range 6-97\%) and 'Stakeholder Involvement' (41\%; Range 1185\%). The poorest scoring domain was 'Applicability' (31\%; Range 3-74\%). Most CPGs were recommended for future use either with (63\%) or without modifications (18\%). A small number were not recommended for future use (14\%) or reviewers did not agree on recommending the CPG (5\%). The overall mean CPG quality score was 4 out of 7 (Range 27). The mean ICC of 0.74 indicated substantial agreement between reviewers. Conclusions: The quality of international CPGs in Ktx was variable, and most CPGs lacked key aspects of methodological robustness and transparency. Improvements in methodology, patient involvement and strategies for implementation are required. 


\section{Introduction}

Kidney donation and transplantation are complex and evolving fields. Over 84,000 kidney transplants were estimated as carried out globally in 2015, based on the Global Observatory on Donation and Transplantation data, produced by the WHO-ONT collaboration. ${ }^{1}$ Clinical Practice Guidelines (CPGs), defined as "systematically developed statements to assist practitioner and patient decisions about appropriate health care for specific clinical circumstances ${ }^{2}$ are essential for the development of protocols in transplant centres. CPGs should be evidence-based and of high quality to ensure these protocols reflect a good standard of clinical care and drive improvements in patient and clinical outcomes.

Variability in the quality of United Kingdom (UK) CPGs in all aspects of kidney transplantation however has been previously identified. ${ }^{3}$ Using the Appraisal of Guidelines for Research and Evaluation (AGREE) II instrument, the methodological rigour and transparency of 13 UK CPGs published between 2010 and 2017 were critically assessed. UK CPGs scored satisfactorily overall but considerable variation in domain scores both within and across CPGs were identified. In another study, also using AGREE II, the quality of 13 CPGs for malignancy screening among solid organ transplant recipients were shown to demonstrate considerable variability and weakness in quality. ${ }^{4}$ The quality of 10 evidencebased CPGs and consensus statements focussed on the screening and follow-up of living kidney donors published between 1996-2010 from Australia, UK, United States, Continental Europe, and Canada were also shown to lack methodological rigour when examined with AGREE, an earlier model of the AGREE II. ${ }^{5}$

The aim of this systematic review was to critically appraise international CPGs on all aspects of kidney transplantation and donation. The AGREE II was used to assess the methodological rigour and transparency of the guideline development process. 


\section{Methods}

\section{Identification of CPGs}

This systematic review of international CPGs was registered with the PROSPERO database of systematic review protocols (PROSPERO ID: CRD42015027356). The review was reported in line with the Preferred Reporting Items for Systematic Reviews and MetaAnalyses (PRISMA) statement. The methods for this systematic review have been previously described. ${ }^{3}$ Briefly, relevant CPGs published from 2010 until April 2017 were identified via MEDLINE, Embase, and the National Guideline Clearinghouse and the National Health Service (NHS) and National Institute for Health and Care Excellence (NICE) evidence search platform. The full search strategy is provided in Materials and Methods, SDC, http://links.lww.com/TP/B574. Searches included keywords and MeSH terms for kidney transplantation, combined with terms for CPGs and were limited to the English language. In addition, 1 author (KO) manually searched the websites of international transplantation and nephrology societies, the United States Public Health Service and the World Health organization (WHO). A full list of included societies is available in Materials and Methods, SDC, http://links.lww.com/TP/B574. Included CPGs from these searches were checked by a second author (LP).

CPGs and consensus statements published by international societies or experts where the main aim of the paper was to provide guidelines and/or recommendations specific to kidney transplantation or kidney donation were included. Where multiple versions of a CPG were identified, the most recent full publication was included. Papers not aimed specifically for kidney transplantation were included if they comprised a chapter designated to kidney transplantation. Two authors (KO and RR) independently reviewed the abstracts of all potentially eligible studies and made the final selection of studies to include based on their full texts. The same 2 authors independently extracted the following data from all included 
studies: author, year, title, organisation, funding body and whether patients had been involved in the preparation of the guideline. Patient involvement was considered met if the guideline explicitly described that a patient representative was included in the working group and contributed to the development of the CPG.

\section{Critical Appraisal with AGREE II}

The AGREE II and the method used to critically appraise CPGs with AGREE II has been previously described in detail. ${ }^{3}$ Briefly, the AGREE II consists of 23 items organised into the following 6 quality domains: i) Scope and Purpose, ii) Stakeholder Involvement, iii) Rigour of Development, iv) Clarity of Presentation, v) Applicability, and vi) Editorial Independence (see Materials and Methods, SDC, http://links.lww.com/TP/B574), in addition to 2 overall items. Each of the 23 items are scored on a 7 point Likert scale from 1 (strongly disagree) to 7 (strongly agree) and a domain score is calculated which involves summing up all of the scores of the individual items in a domain and scaling the total as a percentage of the maximum possible score for that domain (Range: 0-100\%). For the first overall item, appraisers rate the quality of the entire CPG on the same Likert scale. For the second overall item, appraisers decide whether they would consider the CPG appropriate for future use, and answer with either 'Yes', 'Yes with Modifications', or 'No'.6

Each CPG was critically evaluated by 3 appraisers, including 1 transplant clinician and 2 methodologists using AGREE II. All appraisers completed the AGREE II Tutorial and Practice Exercise before commencing the critical appraisal of CPGs.

Appraisers were asked to review and where appropriate revise their initial ratings on any item where their score differed to the other 2 appraisers' scores by $\geq 5$ points (ie, 1 or 2 versus 7 and 1 versus 6). Initial and adjusted scores were calculated and results presented are those of adjusted scores. 


\section{Interrater Reliability}

The Intraclass Correlation Coefficient (ICC) was used to calculate interrater reliability. ${ }^{7}$ Twoway mixed model statistical analyses were performed using MedCalc for Windows, version 15.11.0. ${ }^{8}$ The ICC analysis included average measures for absolute agreement and the degree of agreement was quantified using the following definitions: $\mathrm{ICC}=<0.20$, slight agreement; ICC $=0.21-0.40$, fair agreement; ICC $=0.41-0.60$, moderate agreement; ICC $=0.61-0.80$, substantial agreement; 0.81-1.00, almost perfect agreement. ${ }^{9}$

\section{Results}

\section{Included Studies}

Systematic searches resulted in 3168 records of which 115 CPGs were subsequently included in this systematic review. ${ }^{10-125}$ A literature flow diagram is shown in Figure 1.

CPGs were developed in the following countries; Australia ( $n=35)$, Australia \& New Zealand $(n=2)$, Brazil $(n=1)$, Canada $(n=4)$, Denmark $(n=1)$, Europe $(n=9)$, Europe \& USA $(n=1)$, France $(n=2)$, Germany $(n=2)$, India $(n=2)$, International $(n=7)$, Iran $(n=1)$, Italy $(n=1)$, Japan $(n=3)$, Nordic Countries $(n=1)$, Spain $(n=6)$, United Kingdom $(n=16)$, USA $(n=20)$ and USA \& Canada $(n=1)$. The majority of CPGs were from developed countries (97\%) according to the International Statistical Institute World Bank Country Classifications ${ }^{126}$ with a small minority from the developing countries Brazil, Iran and India (3\%).

The highest number CPGs were published in $2010(n=25)$, the remainder in $2011(n=19)$, $2012(n=9), 2013(n=15), 2014(n=13), 2015(n=15), 2016(n=16)$ and $2017(n=3)$.

CPGs were categorised according to their main topic, and most CPGs were published on living donation $(n=22)$. Other categories included infections $(n=18)$, recipient care $(n=15)$, recipient assessment $(n=9)$, deceased donation $(n=9)$, nutrition $(n=9)$, cardiovascular and lipid complications $(n=6)$, antibodies $(n=4)$, immunosuppression $(n=3)$, mixed aspects of 
transplantation including CPGs reporting on multiple aspects of transplantation $(n=6)$, imaging and biopsies $(n=5)$, and other aspects of transplantation $(n=9)$.

\section{Domain Scores}

Domain scores and overall scores, including mean and ranges are shown in Table 1. The highest domain score across all CPGs was 'Scope and Purpose' (80\%; range 30-100\%), followed by 'Clarity of Presentation' (77\%; range 43-98\%), 'Editorial independence' (52\%; range 0-94\%), 'Rigour of Development' (47\%; range 6-97\%), 'Stakeholder Involvement' (41\%; range 11-85\%) and 'Applicability' (31\%; range 3-74\%). Domain scores and overall scores for all CPGs are plotted in Figure 2. 'Editorial independence' had the largest range of scores, whilst 'Clarity of Presentation' had the smallest range.

\section{Overall Scores}

The overall score ranged from 2-7 out of 7 across CPGs. 51 CPGs scored $\geq 5$ (44\%), whilst 64 scored $<5(56 \%)$.

Overall, 72 CPGs were recommended for future use with modifications (63\%), 21 were recommended for use without modifications (18\%), 16 were not recommended (14\%) and for 6 CPGs, appraisers did not agree whether the CPG should be recommended (5\%).

\section{Individual Item scores}

The highest and lowest scoring individual items are shown in Table 2. Mean compliance to AGREE items ranged from $28 \%$ to $86 \%$. The largest range in appraiser scores for 1 item was for 'a procedure for updating the guideline is provided' (10-100\%). 
Patient Involvement and Funding Body

Only 6 CPGs explicitly described in the guideline document that a patient representative was included in the working group and had contributed to the development of the guideline.

The majority of CPGs $(n=71)$ did not describe sources of funding for the development of the CPG. Of those that described funding sources $(n=44)$, the majority were funded by nonindustry $(n=27)$, followed by industry $(n=7)$, a mixture of industry and nonindustry $(n=4)$, whilst 6 CPGs stated that no funding was received.

\section{Interrater Reliability}

The Intraclass Correlation Coefficient across CPGs ranged from 0.28 to 0.92 indicating a fair to almost perfect level of interrater agreement. The average interrater reliability was substantial at 0.74 .

\section{Original scores}

Ninety-three item score adjustments occurred across CPGs. Score adjustments most commonly occurred in the domain 'Editorial Independence', specifically for item 22 (The views of the funding body have not influenced the content of the guideline). Item score adjustments did not alter the average domain scores across CPGs, and there was only 1 difference in the order from highest to lowest scoring items. Item 10 (The methods for formulating the recommendations are clearly described) moved up from from $15^{\text {to }} 14^{\text {th }}$ position and item 22 moved down from $14^{\text {th }}$ to $15^{\text {th }}$ position. There were no adjustments across CPGs for the 2 overall ratings. 


\section{Discussion}

Variability in the methodology and quality of 115 CPGs in kidney transplantation was found in this systematic review. The highest scoring domain was 'Scope and Purpose' followed by 'Clarity of presentation', which is consistent with previous international studies where these domains have also scored highest. ${ }^{3-5,127,128}$ These 2 domains are important because they look at the overall language, structure, and format of the guideline as well as the overall aim, health questions, and target population. Simple, easy to understand CPGs appear to be the most accessed by clinicians and more likely to be implemented. ${ }^{129-131}$ The majority of CPGs adhered well to the items within these domains, indicating that guideline developers worldwide may understand the value and importance of these components. It may also be that the fulfilment of these components does not require a large amount of resources. ${ }^{132}$ It is encouraging that guideline developers are getting these aspects correct, as without adherence to these domains, CPGs may form cumbersome, complex documents that are likely ineffectual in clinical practice.

The poorest scoring domain was 'applicability' which is consistent with previous studies. . $^{3-}$ 5,127 All items in this domain scored poorly across CPGs. The 'applicability' domain examines whether CPGs have provided advice or tools for putting recommendations into practice, described facilitators and barriers in implementation, considered the resource implications of applying recommendations and presented monitoring or auditing criteria. Unlike other domains, adhering to the aspects of 'applicability' may require a larger amount of resources via the implementation of pilot testing, economic evaluations, educational tools and patient leaflets. ${ }^{6}$ Useful CPGs however are those that can be adapted to clinical practice, not those that merely excel in theoretical content, and CPGs that are not clinically applicable arguably waste time and resources when recommendations are not utilised by the intended health practices. ${ }^{130}$ Decision making at the point of care may be compromised as without 
accessibility to reliable and replicable guidance, uncertainty remains. Treatment may be potentially delayed and the emergence of inconsistencies which creates difficulty when assessing outcomes. A lack of proper consideration of the underlying evidence or poor clarity in presentation will also affect clinician's confidence in the guidelines, meaning that adherence is less likely. Moreover, there is the potential harm to healthcare systems when limited resources are expended on prescribed interventions that are unaffordable, or compromise operating efficiency. ${ }^{133}$ Despite this, developers continuously overlook the applicability of CPGs. Organisations might need to consider refraining in developing CPGs unless they have the necessary funding and resources to address these aspects.

Comparatively, the domains 'Rigour of Development' and 'Stakeholder Involvement' scored slightly better, although still averaged poorly overall. Described as the strongest indicator for guideline quality, the domain 'rigour of development' examines the processes used to gather and synthesise the evidence. ${ }^{127}$ CPGs based on poor quality evidence risk the recommendation of suboptimal, ineffective or even harmful practices. ${ }^{133}$ The use of systematic methods in the searching and selection of evidence are scrutinised in this domain, as well as reporting the strengths and limitations of evidence used to inform recommendations via specific instruments such as GRADE and the Jadad scale. Informal tools may also be utilised, but the essential component is transparently reporting all methods used in the identification, inclusion, and utilisation of the evidence. Many CPGs are developed with low-level evidence or without the inclusion of evidence, instead based on expert opinion. ${ }^{134,135}$ The rationale behind this is that they provide continuity to clinical practice where there is a need for guidance and the evidence is poor. Reporting all methodological aspects is therefore particularly essential to allow the users of CPGs to judge the validity of the content. 
Also examined within this domain, is the undertaking of external reviews and including a procedure and date for CPG revision, items where CPGs again scored poorly. The external review is an important aspect as those individuals not directly involved in the process of CPG development have an opportunity to examine recommendations. Lack of awareness, familiarity and agreement of CPGs have been identified as barriers to their usage and adherence to recommendations. ${ }^{131,136}$ The inclusion of clinicians as external reviewers may encourage those within their practice to be more engaged with the implementation of guidance. ${ }^{137}$ Involving those outside the working group may also help to ensure that recommendations are relevant, reliable and free from bias. According to AGREE II, external reviewers should consist of both clinical and methodological experts. Also recommended is publicly documenting the methodology utilised, as well as all reviewer criticisms, and the rationale for any modifications that did or did not occur to ensure transparency. ${ }^{138}$

There does not appear to be consensus on the timeframe for CPG review, possibly because this is largely dependent on the content of the CPG and how regularly new, relevant evidence materialises. ${ }^{139}$ Studies examining the validity of CPGs in health care show variable results where a fifth of CPGs developed in the Spanish National Health System were out of date within 5 years. ${ }^{140}$ Half of CPGs published by the US Agency for Healthcare Research and Quality were obsolete after 5.8 years, and $86 \%$ of CPGs developed by the UK National Institute for Health and Clinical Excellence were still up to date 3 years after publication. ${ }^{141,142}$ The challenge for CPG developers is to ensure recommendations are valid, reliable and up to date without wasting time and resources in identifying new evidence if there is no significant change, or the evidence does not warrant changes to current recommendations. ${ }^{142}$ The Transplant Library is a resource that provides quick access to high quality evidence that could warrant changes to recommendations. ${ }^{143}$ For improvements in this item, developers should document the proposed date for CPG review detailing clearly the 
intended methodology, monitor the literature regularly, and update recommendations when new evidence suggests the need for modification.

The poorest scoring item across CPGs was seeking the views and preferences of the target population, which is 1 of 3 items included in the domain 'stakeholder involvement'. The importance of patient preferences to clinical decision-making has gained steady momentum and has led to advocating the involvement of patient and public representatives in the development of CPGs. ${ }^{144,145}$ A collaborative approach is recommended which allows the formulation of CPGs that are not only evidence-based but that are more likely to be adhered to by patients and therefore useful in clinical practice. The incorporation of a patient representative in the working group and in the development of CPGs was examined in this systematic review. Disappointingly, very few CPGs included a patient representative. Similar findings are reported in a systematic review spanning 2 decades between 1980 and 2007 highlighting that little progress has been made with improving this area. ${ }^{127}$ The Guideline International Network provide a useful online toolkit which details practical support for obtaining patient perspectives via 3 main strategies; consultation, participation and communication. ${ }^{146}$ Guideline developers would benefit from incorporating such examples in the development of CPGs to ensure they are clinically applicable to the target population.

The domain 'editorial independence' examines competing interests declarations and whether recommendations may be biased by the views of funding bodies or CPG developers. CPGs performed moderately in this domain and the majority of CPGs did not describe details of funding. CPG developers may underestimate the importance of addressing and declaring all competing interests and financial aid. Alternatively, excluding this information may be a sinister way of concealing the exchange of professional or financial gains for the promotion of specific recommendations. CPGs are widely distributed and have the power to influence 
clinical practice protocols and unethical or unsafe recommendations must not be put forward for personal or organisational gain. Preventing competing interests in CPG development is a difficult and complex task. Excluding individuals with conflicts of interest in the involvement of CPG development is a possible solution, however this is dependent on self-reporting and evidence suggests that many individuals are not transparent, or even aware of their own conflicts of interest. ${ }^{147}$ It may also be difficult to exclude certain individuals' with conflicts of interest as their expertise is not replaceable. ${ }^{148}$ Similarly, considerable time and resources are involved in the development of CPGs and funding may not be available from nonconflicting organisations. Conflicts of interest and involvement of funders in CPG development should be reduced as much as possible to avoid biased guidelines. ${ }^{148} \mathrm{CPG}$ users would benefit from explicit, publicly accessible details of funding and conflicts of interest, which will increase their confidence about the reliability of CPGs for clinical practice.

This systematic review has limitations. Included CPGs were published in English only, the majority of which were developed in Australia and the USA. Therefore, the overall mean results were largely influenced by the $\mathrm{CPG}$ development procedures in place in these countries. Systematic searches located CPGs published in journals however, manual searches were constrained to include international transplantation societies that would be producers of CPGs. The majority of these societies were located in developed countries indicating that the quality of CPGs in developing countries are likely underrepresented in this systematic review. A study that surveyed international members of The Transplantation Society on the uptake of a CPG on cytomegalovirus management in solid organ transplantation reported that $20 \%$ of respondents were from developing countries. ${ }^{149}$ It may be that CPGs from developing countries are sparse and this community relies on CPGs published by other national and international organisations. A large portion of CPGs included in this systematic review were produced in 2010 and 2011 and could be considered out of date. However, as these CPGs 
have not been updated and are currently available for use in clinical practice, the inclusion of these CPGs is relevant to the overall quality of international CPGs. CPGs on all aspects of kidney transplantation and kidney donation were included in the systematic review, enabling an extensive range of topic areas to be covered. However due to this variability, recommendations could not be compared across CPGs.

A strength of the systematic review is the use of 3 appraisers for all CPGs, which included individuals with a methodological background and kidney transplant clinicians. The rationale for inclusion of both was to ensure that the examination and interpretation of CPGs was representative of differences in clinical and methodological opinion. Appraisals were completed individually and multiple appraisers with differing affiliations were utilised to limit the influence of confirmation bias. All appraisers completed the training module before appraising any CPGs and the ICC demonstrates that there was a good cohesion between all appraisers.

The AGREE II instrument incorporates specific criteria for all 23 items, however is limited by a lack of guidance on how to make the overall assessments. Appraisers could have rated these differently depending on which aspects of CPG development they felt were most representative of overall CPG quality. ${ }^{127}$ There is also no cut-off to distinguish between high and low quality clinical practice guidelines, an aspect identified as important to many users. ${ }^{150}$ The number of items in each domain is not consistent and items attributed to "rigour of development' or 'applicability' will have less of an effect on the overall domain score compared to items in the 'editorial independence' domain. As with all critical appraisals, the AGREE II is also dependent on methodological reporting. CPG developers may have used utilised methods not described in the document. 


\section{Conclusion}

The quality of international CPGs in kidney transplantation requires significant improvement. Only a small number of CPGs scored well overall and were recommended for future use without modifications. The majority scored poorly overall and required modification, and a small number were not recommended for future use. All CPGs demonstrated variability in domain and item scores with most performing well in the domains 'scope and purpose' and 'clarity of presentation' and poorly in the domain 'applicability'. CPG developers should pay closer attention to the components of the AGREE II and endeavour to incorporate them into CPGs. Many aspects could be easily improved without an additional burden on time and

resources. High-quality CPGs will support evidence-based decision-making and will ultimately lead to better outcomes for kidney transplant recipients. 


\section{REFERENCES}

1. Organ Donation and Transplantation Activities 2015. Global Observatory on Donation and Transplantation (GODT) data, produced by the WHO-ONT collaboration. Available from: http://www.transplant-observatory.org. Accessed October 31, 2017

2. Institute of Medicine (US) Committee to Advise the Public Health Service on Clinical Practice Guidelines, Field MJ, Lohr KN. Clinical Practice Guidelines: Directions for a New Program. Washington DC: National Academies Press US; 1990.

3. O'Donoghue KJM, Reed RD, Knight SR, et al. Systematic review of clinical practice guidelines in kidney transplantation. BJS Open. 2017; 1(4): 97-105.

4. Acuna SA, Huang JW, Scott AL, et al. Cancer Screening Recommendations for Solid Organ Transplant Recipients: A Systematic Review of Clinical Practice Guidelines. Am J Transplant. 2017; 17(1): 103-114.

5. Tong A, Chapman JR, Wong G, de Bruijn J, Craig JC. Screening and follow-up of living kidney donors: a systematic review of clinical practice guidelines. Transplantation. 2011; 92(9): 962-72.

6. Brouwers M, Kho ME, Browman GP, et al on behalf of the AGREE Next Steps Consortium. AGREE II: Advancing guideline development, reporting and evaluation in healthcare. Can Med Assoc J. 2010; 182: E839-842.

7. Shrout PE, Fleiss JL. Intraclass correlations: uses in assessing rater reliability. Psychol Bull. 1979; 86(2): 420-8. 
8. MedCalc Statistical Software version 15.11.0 (MedCalc Software bvba, Ostend, Belgium; https://www.medcalc.org; 2016)

9. Landis JR, Koch GG. The measurement of observer agreement for categorical data. Biometrics. 1977; 33(1):159-74.

10. Mackie F, CARI. The CARI guidelines. Potential child-bearing donors. Nephrology (Carlton). 2010; 15 Suppl 1: S99-100.

11. Munn S, Cari. The CARI guidelines. Assessment of donor kidney anatomy. Nephrology (Carlton). 2010. 15 Suppl 1: S96-98.

12. van Hardeveld E, Tong A, CARI. The CARI guidelines. Psychosocial care of living kidney donors. Nephrology (Carlton). 2010; 15 Suppl 1: S80-7.

13. Kanellis J, CARI. The CARI guidelines. Justification for living donor kidney transplantation. Nephrology (Carlton). 2010; 15 Suppl 1: S72-9.

14. Cohney S, Kanellis J, Howell M. CARI. The CARI guidelines. Donor renal function. Nephrology (Carlton). 2010; 15 Suppl 1: S137-45.

15. Isbel N, CARI guidelines. The CARI guidelines. Donors at risk: obesity. Nephrology (Carlton). 2010; 15 Suppl 1: S121-32.

16. Ierino F, Boudville N, Kanellis J, CARI. The CARI guidelines. Donors at risk: hypertension. Nephrology (Carlton). 2010; 15 Suppl 1: S114-20. 
17. Ierino F, Kanellis J, CARI. The CARI guidelines. Donors at risk: haematuria. Nephrology (Carlton). 2010; 15 Suppl 1: S111-3.

18. Boudville N, Kanellis J, CARI. The CARI guidelines. Donors at risk: proteinuria. Nephrology (Carlton). 2010; 15 Suppl 1: S106-10.

19. Boudville N, Isbel N, CARI. The CARI guidelines. Donors at risk: impaired glucose tolerance. Nephrology (Carlton). 2010; 15 Suppl 1: S133-6.

20. Gibbons N, Nicol D, CARI. The CARI guidelines. Surgical techniques in living donor nephrectomy. Nephrology (Carlton). 2010; 15 Suppl 1: S88-95.

21. National Institute for Health and Clinical Excellence. Single-port laparoscopic nephrectomy. Interventional procedures guidance [IPG414]. 2011. Available from: https://www.nice.org.uk/guidance/ipg414. Accessed August 9, 2015.

22. Compiled by a Joint Working Party of The British Transplantation Society and The Renal Association Joint Working Party. Living Donor Kidney Transplantation (Third Edition). 2011. Available from: https://bts.org.uk. Accessed February 25, 2015.

23. Melcher ML, Blosser CD, Baxter-Lowe LA, et al. Dynamic challenges inhibiting optimal adoption of kidney paired donation: findings of a consensus conference. Am J Transplant. 2013; 13(4): 851-60. 
24. Levi ME, Kumar D, Green M, et al. Considerations for screening live kidney donors for endemic infections: a viewpoint on the UNOS policy. Am J Transplant. 2014; 14(5): 100311.

25. Tushla L, Rudow DL, Milton J, et al. Living-Donor Kidney Transplantation: Reducing Financial Barriers to Live Kidney Donation--Recommendations from a Consensus Conference. Clin J Am Soc Nephrol. 2015; 10(9): 1696-702.

26. Moore DR, Serur D, Rudow DL, et al. Living Donor Kidney Transplantation: Improving Efficiencies in Live Kidney Donor Evaluation--Recommendations from a Consensus Conference. Clin J Am Soc Nephrol. 2015; 10(9): 1678-86.

27. Tan JC, Gordon EJ, Dew MA, et al. Living Donor Kidney Transplantation: Facilitating Education about Live Kidney Donation--Recommendations from a Consensus Conference. Clin J Am Soc Nephrol. 2015; 10(9): 1670-7.

28. Waterman AD, Morgievich M, Cohen DJ, et al. Living Donor Kidney Transplantation: Improving Education Outside of Transplant Centers about Live Donor Transplantation-Recommendations from a Consensus Conference. Clin J Am Soc Nephrol. 2015; 10(9): 165969.

29. LaPointe Rudow D, Hays R, Baliga P, et al. Consensus conference on best practices in live kidney donation: recommendations to optimize education, access, and care. Am J Transplant. 2015; 15(4): 914-22. 
30. Rodrigue JR, Kazley AS, Mandelbrot DA, et al. Living Donor Kidney Transplantation: Overcoming Disparities in Live Kidney Donation in the US--Recommendations from a Consensus Conference. Clin J Am Soc Nephrol. 2015; 10(9): 1687-95.

31. Working Party of the British Transplantation Society. UK Guidelines for Living Organ Donation from Prisoners. 2015. Available from: https://bts.org.uk/wpcontent/uploads/2016/09/04_BTS_Donation_Prisoners-1.pdf. Accessed August 9, 2015.

32. Gracey, D. Kidney Health Australia CARI guidelines. HIV, HBV and HCV infection. 2011. Available from: http://www.CARI.org.au. Accessed March 11, 2016.

33. McTaggart S. Kidney Health Australia CARI guidelines. Paediatric recipient. 2011. Available from: http://www.CARI.org.au. Accessed March 11, 2016.

34. Mulley, W. Kidney Health Australia CARI guidelines. Malignancy. 2011. Available from: http://www.CARI.org.au. Accessed March 11, 2016.

35. Pilmore, H. Kidney Health Australia CARI guidelines. Cardiovascular Disease. 2011. Available from: http://www.CARI.org.au. Accessed April 21, 2016.

36. Russell C. Kidney Health Australia CARI guidelines. Obesity in renal transplantation. 2011. Available from: http://www.CARI.org.au. Accessed April 21, 2016.

37. Campbell, C. Kidney Health Australia CARI guidelines. Diabetes Mellitus. 2011. Available from: http://www.CARI.org.au. Accessed April 21, 2016. 
38. Dudley C, Harden P. Renal Association Clinical Practice Guideline on the assessment of the potential kidney transplant recipient. Nephron Clin Pract. 2011; 118 Suppl 1: c209-24

39. Guideline development group. Clinical Practice Guideline on management of patients with diabetes and chronic kidney disease stage $3 \mathrm{~b}$ or higher (eGFR $<45 \mathrm{~mL} / \mathrm{min}$ ). Nephrol Dial Transplant. 2015; 30 Suppl 2: ii1-142.

40. Segall L, Nistor I, Pascual J, et al. Criteria for and Appropriateness of Renal Transplantation in Elderly Patients With End-Stage Renal Disease: A Literature Review and Position Statement on Behalf of the European Renal Association-European Dialysis and Transplant Association Descartes Working Group and European Renal Best Practice. Transplantation. 2016; 100(10): e55-65.

41. Mackie F, CARI. The CARI guidelines. Donor-specific transfusions. Nephrology (Carlton). 2010; 15 Suppl 1: S101-5.

42. Knoll GA, Blydt-Hansen TD, Campbell P, et al. Canadian Society of Transplantation and Canadian Society of Nephrology commentary on the 2009 KDIGO clinical practice guideline for the care of kidney transplant recipients. Am J Kidney Dis. 2010; 56(2): 219-46.

43. Saif I, Adkins A, Kewley V, Woywodt A, Brookes V. Routine and emergency management guidelines for the dental patient with renal disease and kidney transplant. Part 1. Dent Update. 2011; 38(3):179-82, 185-6. 
44. Saif I, Adkins A, Kewley V, Woywodt A, Brookes V. Routine and emergency management guidelines for the dental patient with renal disease and kidney transplant. Part 2. Dent Update. 2011; 38(4): 245-8, 250-1.

45. Chadban SJ, Barraclough KA, Campbell SB, et al. KHA-CARI guideline: KHA-CARI adaptation of the KDIGO Clinical Practice Guideline for the Care of Kidney Transplant Recipients. 2012. Available from: http://www.CARI.org.au. Accessed January 11, 2016.

46. Kidney Disease: Improving Global Outcomes (KDIGO) Blood Pressure Work Group. KDIGO Clinical Practice Guideline for the Management of Blood Pressure in Chronic Kidney Disease. Kidney Inter. Suppl. 2012; 2: 337-414.

47. Pascual J, Alonso A, Burgos D, Cruzado JM, Serón D, Grupo Español de Consenso sobre disfunción renal crónica en pacientes. Chronic renal dysfunction in kidney transplant recipients. Consensus Document. Spanish Consensus Group on Renal Dysfunction in Kidney Transplantation Patients. Nefrologia. 2012; 32 Suppl 2: 1-28.

48. Expert Panel on Urologic Imaging, Taffel MT, Nikolaidis P, et al. ACR Appropriateness Criteria® Renal Transplant Dysfunction. J Am Coll Radiol. 2017; 14(5S): S272-S281.

49. Hornum M, Lindahl JP, von Zur-Mühlen B, Jenssen T, Feldt-Rasmussen B. Diagnosis, management and treatment of glucometabolic disorders emerging after kidney transplantation: a position statement from the Nordic Transplantation Societies. Transpl Int. 2013; 26(11): 1049-60. 
50. Compiled by a Working Party of The British Transplantation Society. Management of the Failing Kidney Transplant. 2014. Available from: https://bts.org.uk. Accessed February 25, 2015.

51. Huprikar S, Danziger-Isakov L, Ahn J, et al. Solid organ transplantation from hepatitis B virus-positive donors: consensus guidelines for recipient management. Am J Transplant. 2015; 15(5): 1162-72.

52. Morrone LF, Bolasco P, Camerini C, et al. Vitamin D in patients with chronic kidney disease: a position statement of the Working Group "Trace Elements and Mineral Metabolism" of the Italian Society of Nephrology. J Nephrol. 2016; 29(3): 305-328.

53. Vaccination guidelines in patients with chronic kidney disease and renal transplant recipients travelling abroad. Indian Journal of Nephrology. 2016; 26(Suppl 1): S26-S28.

54. Guidelines for vaccination in kidney transplant recipients. Indian Journal of Nephrology. 2016;26(Suppl 1):S19-S25.

55. Neuberger JM, Bechstein WO, Kuypers DR, et al. Practical Recommendations for Longterm Management of Modifiable Risks in Kidney and Liver Transplant Recipients: A Guidance Report and Clinical Checklist by the Consensus on Managing Modifiable Risk in Transplantation (COMMIT) Group. Transplantation. 2017; 101(4S Suppl 2): S1-S56.

56. Baker RJ, Mark PB, Patel RK, Stevens KK, Palmer N. Post-Operative Care in the Kidney Transplant Recipient. 2017. Available from: https://bts.org.uk. Accessed March 21, 2017. 
57. British Thoracic Society Standards of Care Committee and Joint Tuberculosis

Committee, Milburn H, Ashman N, et al. Guidelines for the prevention and management of Mycobacterium tuberculosis infection and disease in adult patients with chronic kidney disease. Thorax. 2010; 65(6): 557-70.

58. Goodman, D. Kidney Health Australia CARI guidelines. Treatment of Cytomegalovirus disease in renal transplant recipients. 2011. Available from: http://www.CARI.org.au. Accessed March 11, 2016.

59. Pussell, BA. Kidney Health Australia CARI guidelines. Prophylaxis for Cytomegalovirus infection in patients following renal transplantation. 2011. Available from: http://www.CARI.org.au. Accessed April 21, 2016.

60. Pilmore, H. Kidney Health Australia CARI guidelines. Diagnostic tests for Cytomegalovirus in renal transplantation. 2011. Available from: http://www.CARI.org.au. Accessed April 21, 2016.

61. Pilmore, H. Kidney Health Australia CARI guidelines. Pre-emptive treatment of Cytomegalovirus. 2011. Available from: http://www.CARI.org.au. Accessed April 21, 2016.

62. de la Torre-Cisneros J, Fariñas MC, Castón JJ, et al. GESITRA-SEIMC/REIPI recommendations for the management of cytomegalovirus infection in solid-organ transplant patients. Enferm Infecc Microbiol Clin. 2011; 29(10): 735-58. 
63. British Transplantation Society. The Prevention and Management of CMV Disease after Solid Organ Transplantation. (Third Edition). 2011. Available from: https://bts.org.uk. Accessed August 9, 2015.

64. Singh N, Huprikar S, Burdette SD, et al. Donor-derived fungal infections in organ transplant recipients: guidelines of the American Society of Transplantation, infectious diseases community of practice. Am J Transplant. 2012; 12(9): 2414-28.

65. Razonable RR, Humar A, AST Infectious Diseases Community of Practice.

Cytomegalovirus in solid organ transplantation. Am J Transplant. 2013; 13 Suppl 4: 93-106.

66. Parasuraman R, Julian K, AST Infectious Diseases Community of Practice. Urinary tract infections in solid organ transplantation. Parasuraman R et al. Am J Transplant. 2013; 13 Suppl 4: 327-36.

67. Hirsch HH, Randhawa P, AST Infectious Diseases Community of Practice. BK polyomavirus in solid organ transplantation. Am J Transplant. 2013; 13 Suppl 4: 179-88.

68. Bratzler DW, Dellinger EP, Olsen KM, et al. Clinical practice guidelines for antimicrobial prophylaxis in surgery. Surg Infect (Larchmt). 2013; 14(1): 73-156.

69. AIDS Working Group (GESIDA) of the Spanish Society of InfectiousDiseases and Clinical Microbiology (SEIMC), Spanish Society of Nephrology (S.E.N.), Spanish Society of Clinical Chemistry and Molecular Pathology (SEQC), et al. Consensus document on the management of renal disease in HIV-infected patients. Nefrologia. 2014; 34 Suppl 2: 1-81. 
70. Lucas GM, Ross MJ, Stock PG, et al. Clinical practice guideline for the management of chronic kidney disease in patients infected with HIV: 2014 update by the HIV Medicine Association of the Infectious Diseases Society of America. Clin Infect Dis. 2014; 59(9): e96138.

71. Vidal E, Cervera C, Cordero E, et al. Management of urinary tract infection in solid organ transplant recipients: Consensus statement of the Group for the Study of Infection in Transplant Recipients (GESITRA) of the Spanish Society of Infectious Diseases and Clinical Microbiology (SEIMC) and the Spanish Network for Research in Infectious Diseases (REIPI). Enferm Infecc Microbiol Clin. 2015; 33(10): 679.e1-679.e21.

72. Compiled by a Working Party of The British Transplantation Society. Kidney \& Pancreas Transplantation in Patients with HIV. Second Edition. 2015. Available from: https://bts.org.uk. Accessed August 9, 2015.

73. Antimicrobial prophylaxis for pneumocystis jiroveci pneumonia (PCP) after solid organ transplantation (SOT). 2015. Available from: https://www.cincinnatichildrens.org. Accessed April 5, 2016.

74. Yamamoto S, Shigemura K, Kiyota H, et al. Essential Japanese guidelines for the prevention of perioperative infections in the urological field: 2015 edition. Int J Urol. 2016 Oct; 23(10): 814-824.

75. Westphal GA, Caldeira Filho M, Vieira KD, et al. Guidelines for potential multiple organ donors (adult). Part III: organ-specific recommendations. Rev Bras Ter Intensiva. 2011; 23(4): 410-25. 
76. Wunderlich H, Brockmann JG, Voigt R, et al. DTG procurement guidelines in heart beating donors. Transpl Int. 2011; 24(7): 733-57.

77. Compiled by a Working Party of The British Transplantation Society. Transplantation from deceased donors after circulatory death. 2013. Available from: https://bts.org.uk. Accessed February 25, 2015.

78. Antoine C, Mourey F, Prada-Bordenave E, Steering committee on DCD program. How France launched its donation after cardiac death program. Ann Fr Anesth Reanim. 2014; 33(2): $138-43$.

79. Lledo-Garcia E, Riera L, et al. Spanish consensus document for acceptance and rejection of kidneys from expanded criteria donors. Clin Transplant. 2014; 28(10): 1155-1166.

80. Chen J, Fink M, Pleass H, Verran D, Crawford M, Allen R. Surgical Technique for Deceased Donor Abdominal Organ Procurement. ATCA-TSANZ Guidelines G003/2015. 2015. Available from: http://www.tsanz.com.au. Accessed January 20, 2016.

81. Kotloff RM, Blosser S, Fulda GJ, et al. Management of the Potential Organ Donor in the ICU: Society of Critical Care Medicine/American College of Chest Physicians/Association of Organ Procurement Organizations Consensus Statement. Crit Care Med. 2015; 43(6): 1291325.

82. The Transplantation Society of Australia and New Zealand. Clinical Guidelines for Organ Transplantation from Deceased Donors Version 1.0 - April 2016. 2016. Available from: http://www.tsanz.com.au. Accessed April 21, 2016. 
83. van Heurn LW, Talbot D, Nicholson ML, et al. Recommendations for donation after circulatory death kidney transplantation in Europe. Transpl Int. 2016; 29(7): 780-9.

84. Chadban S, Chan M, Fry K, et al. The CARI guidelines. Nutritional management of dyslipidaemia in adult kidney transplant recipients. Nephrology (Carlton). 2010; 15 Suppl 1: S62-7.

85. Chadban S, Chan M, Fry K, et al. The CARI guidelines. Nutritional management of hypertension in adult kidney transplant recipients. Nephrology (Carlton). 2010; 15 Suppl 1: S56-61.

86. Chadban S, Chan M, Fry K, et al. The CARI guidelines. Nutritional management of overweight and obesity in adult kidney transplant recipients. Nephrology (Carlton). 2010; 15 Suppl 1: S52-5.

87. Chadban S, Chan M, Fry K, et al. The CARI guidelines. Nutritional management of hypophosphataemia in adult kidney transplant recipients. Nephrology (Carlton). 2010; 15 Suppl 1: S48-51.

88. Chadban S, Chan M, Fry K, et al. The CARI guidelines. Nutritional interventions for the prevention of bone disease in kidney transplant recipients. Nephrology (Carlton). 2010; 15 Suppl 1: S43-7.

89. Chadban S, Chan M, Fry K, et al. The CARI guidelines. Nutritional management of anaemia in adult kidney transplant recipients. Nephrology (Carlton). 2010; 15 Suppl 1: S402. 
90. Chadban S, Chan M, Fry K, et al. The CARI guidelines. Nutritional management of diabetes mellitus in adult kidney transplant recipients. Nephrology (Carlton). 2010; 15 Suppl 1: S37-9.

91. Chadban S, Chan M, Fry K, et al. The CARI guidelines. Food safety recommendations for adult kidney transplant recipients. Nephrology (Carlton). 2010; 15 Suppl 1: S35-6.

92. Chadban S, Chan M, Fry K, et al. The CARI guidelines. Protein requirement in adult kidney transplant recipients. Nephrology (Carlton). 2010; 15 Suppl 1: S68-71.

93. Dieperink H, Christensen JH, Feldt-Rasmussen B, et al. Danish guidelines for lipidlowering treatment in patients with chronic renal failure. Dan Med J. 2014 ;61(4): C4843.

94. Lentine KL, Costa SP, Weir MR, et al. Cardiac disease evaluation and management among kidney and liver transplantation candidates: a scientific statement from the American Heart Association and the American College of Cardiology Foundation: endorsed by the American Society of Transplant Surgeons, American Society of Transplantation, and National Kidney Foundation. Circulation. 2012; 126(5): 617-63.

95. Kidney Disease: Improving Global Outcomes (KDIGO) Lipid Work Group. KDIGO Clinical Practice Guideline for Lipid Management in Chronic Kidney Disease. Kidney Inter. Suppl. 2013; 3: 259-305.

96. Pilmore H. Kidney Health Australia CARI guidelines. Cardiovascular disease: revascularisation. 2013. Available from: http://www.CARI.org.au. Accessed May 19, 2016. 
97. Dogra G. Kidney Health Australia CARI guidelines. Medical management of coronary artery disease (excluding lipid-lowering therapy). 2012. Available from: http://www.CARI.org.au. Accessed May 19, 2016.

98. Roberts M. Kidney Health Australia CARI guidelines. Heart Failure. 2013. Available from: http://www.CARI.org.au. Accessed May 19, 2016.

99. Tait BD, Süsal C, Gebel HM, et al. Consensus guidelines on the testing and clinical management issues associated with HLA and non-HLA antibodies in transplantation. Transplantation. 2013; 95(1): 19-47.

100. Compiled by a Working Party of The British Transplantation Society. Guidelines for Antibody Incompatible Transplantation (Third Edition). 2016. Available from: https://bts.org.uk/wp-content/uploads/2016/09/02_BTS_Antibody_Guidelines-1.pdf. Accessed September 22, 2016.

101. British Society for Histocompatibility \& Immunogenetics and British Transplantation Society. The detection and characterisation of clinically relevant antibodies in allotransplantation. 2014. Available from: https://bts.org.uk/wpcontent/uploads/2016/09/06_BTS_BSHI_Antibodies-1.pdf. Accessed February 25, 2015.

102. Shehata N, Palda VA, Meyer RM, et al. The use of immunoglobulin therapy for patients undergoing solid organ transplantation: an evidence-based practice guideline. Transfus Med Rev. 2010; 24 Suppl 1: S7-S27. 
103. Harrison JJ, Schiff JR, Coursol CJ, et al. Generic immunosuppression in solid organ transplantation: a Canadian perspective. Transplantation. 2012; 93(7): 657-65.

104. Caillard S, Moulin B, Buron F, et al. Advagraf®, a once-daily prolonged release tacrolimus formulation, in kidney transplantation: literature review and guidelines from a panel of experts. Transpl Int. 2016; 29(8): 860-9.

105. Shipkova M, Hesselink DA, Holt DW, et al. Therapeutic Drug Monitoring of Everolimus: A Consensus Report. Ther Drug Monit. 2016; 38(2): 143-69.

106. Riccabona M, Avni FE, Damasio MB, et al. ESPR Uroradiology Task Force and ESUR Paediatric Working Group--Imaging recommendations in paediatric uroradiology, part V: childhood cystic kidney disease, childhood renal transplantation and contrast-enhanced ultrasonography in children. Pediatr Radiol. 2012; 42(10): 1275-83.

107. Roberts I, Furness P, and Cook T on behalf of the College's Specialty Advisory Committee on Cellular Pathology and the Cancer Services Working Group. Tissue pathway for medical renal biopsies [G061]. 2013. Available from: https://www.rcpath.org/asset/AEAF873A-694A-4435-9C82E2773C1343F5. Accessed August 9, 2015.

108. American College of Radiology (ACR), Society for Pediatric Radiology (SPR), Society of Radiologists in Ultrasound (SRU), American Institute of Ultrasound in Medicine (AIUM). AIUM practice guideline for the performance of an ultrasound examination of solid-organ transplants. J Ultrasound Med. 2014; 33(7):1309-20. 
109. Pisarski P, Schleicher C, Hauser I, Becker JU. German recommendations for pretransplantation donor kidney biopsies. Langenbecks Arch Surg. 2016; 401(2): 133-40.

110. Terminology and Diagnostic Criteria Committee, Japan Society of Ultrasonics in Medicine. Standard method for ultrasound evaluation of renal arterial lesions. J Med Ultrason (2001). 2016; 43(1):1 45-62.

111. European Renal Best Practice Transplantation Guideline Development Group. ERBP Guideline on the Management and Evaluation of the Kidney Donor and Recipient. Nephrol Dial Transplant. 2013; 28 Suppl 2: ii1-71.

112. Karam G, Kälble T, Alcaraz A, et al. Guidelines on Renal Transplantation. 2014. Available from: http://uroweb.org. Accessed January 19, 2016.

113. Nafar M, Firoozan A, Poor-Reza-Gholi F, et al. Kidney donor and recipient perioperative evaluation. Iran J Kidney Dis. 2014 ;8(1): 13-24.

114. Cantarovich M, Blydt-Hansen TD, Gill J, et al. Canadian Forum on Combined Organ Transplantation. Transplantation. 2016; 100(6): 1339-48.

115. European Directorate for the Quality of Medicines \& HealthCare. Guide to the quality and safety of organs for transplantation 6th Edition. 2016. Available from: https://www.edqm.eu/en. Accessed October 14, 2016.

116. Abramowicz D, Hazzan M, Maggiore U, et al. Does pre-emptive transplantation versus post start of dialysis transplantation with a kidney from a living donor improve outcomes 
after transplantation? A systematic literature review and position statement by the Descartes Working Group and ERBP. Nephrol Dial Transplant. 2016; 31(5): 691-7.

117. Taylor CM, Machin S, Wigmore SJ, Goodship TH, Working party from the Renal Association, the British Committee for Standards in Haematology and the British Transplantation Society. Clinical practice guidelines for the management of atypical haemolytic uraemic syndrome in the United Kingdom. Br J Haematol. 2010; 148(1): 37-47.

118. Torregrosa JV, Bover J, Cannata Andía J, et al. Spanish Society of Nephrology recommendations for controlling mineral and bone disorder in chronic kidney disease patients (S.E.N.-M.B.D.). Nefrologia. 2011; 31 Suppl 1: 3-32.

119. Savige J, Gregory M, Gross O, Kashtan C, Ding J, Flinter F. Expert guidelines for the management of Alport syndrome and thin basement membrane nephropathy. J Am Soc Nephrol. 2013; 24(3): 364-75.

120. Fukagawa M, Yokoyama K, Koiwa F, et al. Clinical practice guideline for the management of chronic kidney disease-mineral and bone disorder. Ther Apher Dial. 2013; 17(3): $247-88$.

121. Baumgartner MR, Hörster F, Dionisi-Vici C, et al. Proposed guidelines for the diagnosis and management of methylmalonic and propionic acidemia. Orphanet J Rare Dis. 2014; 9:130. 
122. Jelaković B, Nikolić J, Radovanović Z, et al. Consensus statement on screening, diagnosis, classification and treatment of endemic (Balkan) nephropathy. Nephrol Dial Transplant. 2014; 29(11): 2020-7.

123. Wechalekar AD, Gillmore JD, Bird J, et al. Guidelines on the management of AL amyloidosis. Br J Haematol. 2015; 168(2): 186-206.

124. Loirat C, Fakhouri F, Ariceta G, et al. An international consensus approach to the management of atypical hemolytic uremic syndrome in children. Pediatr Nephrol. 2016; 31(1): 15-39.

125. Newell KA, Formica RN, Gill JS, et al. Integrating APOL1 Gene Variants Into Renal Transplantation: Considerations Arising From the American Society of Transplantation Expert Conference. Am J Transplant. 2017; 17(4): 901-911.

126. International Statistical Institute. https://www.isi-web.org/index.php. Accessed November 7, 2017.

127. Alonso-Coello P, Irfan A, Solà I, et al. The quality of clinical practice guidelines over the last two decades: a systematic review of guideline appraisal studies. Qual Saf Health Care. 2010; 19(6): e58.

128. Burda BU, Chambers AR, Johnson JC. Appraisal of guidelines developed by the World Health Organization. Public Health. 2014; 128(5):444-74. 
129. Francke AL, Smit MC, de Veer AJ, Mistiaen P. Factors influencing the implementation of clinical guidelines for health care professionals: a systematic meta-review. BMC Med Inform Decis Mak. 2008; 8: 38.

130. Sola I, Carrasco JM, Díaz Del Campo P, et al. Attitudes and perceptions about clinical guidelines: a qualitative study with Spanish physicians. PLoS One. 2014; 9(2): e86065.

131. Sinuff T, Eva KW, Meade M, Dodek P, Heyland D, Cook D. Clinical practice guidelines in the intensive care unit: a survey of Canadian clinicians' attitudes. Can J Anaesth. 2007; 54(9): 728-36.

132. Lytras T, Bonovas S, Chronis C, et al. Occupational Asthma guidelines: a systematic quality appraisal using the AGREE II instrument. Occup Environ Med. 2014; 71(2): 81-6.

133. Woolf SH, Grol R, Hutchinson A, Eccles M, Grimshaw J. Clinical guidelines: potential benefits, limitations, and harms of clinical guidelines. BMJ. 1999; 318(7182): 527-30.

134. Venkatesh AK, Savage D, Sandefur B, Bernard KR, Rothenberg C, Schuur JD. Systematic review of emergency medicine clinical practice guidelines: Implications for research and policy. PLoS One. 2017; 12(6): e0178456.

135. Atkins D, Eccles M, Flottorp S, Guyatt GH, Henry D, Hill S, et al. Systems for grading the quality of evidence and the strength of recommendations I: critical appraisal of existing approaches The GRADE Working Group. BMC Health Serv Res. 2004; 4(1): 38. 
136. Cabana MD, Rand CS, Powe NR, et al. Why don't physicians follow clinical practice guidelines? A framework for improvement. JAMA. 1999; 282(15): 1458-65.

137. Lowson K, Jenks M, Filby A, Carr L, Campbell B, Powell J. Examining the implementation of NICE guidance: cross-sectional survey of the use of NICE interventional procedures guidance by NHS Trusts. Implement Sci. 2015; 10:93.

138. Graham R, Mancher M, Wolman DM, Greenfield S, and Steinberg E Institute of Medicine (US) Committee on Standards for Developing Trustworthy Clinical Practice Guidelines, Graham R, Mancher M, et al. Clinical Practice Guidelines We Can Trust. Washington DC: National Academies Press US; 2011.

139. Alonso-Coello P, Martínez García L, Carrasco JM, et al. The updating of clinical practice guidelines: insights from an international survey. Implement Sci. 2011; 6: 107.

140. Martínez García L, Sanabria AJ, García Alvarez E, et al. The validity of recommendations from clinical guidelines: a survival analysis. CMAJ. 2014; 186(16): 12119.

141. Alderson LJ, Alderson P, Tan T. Median life span of a cohort of National Institute for Health and Care Excellence clinical guidelines was about 60 months. J Clin Epidemiol. 2014; 67(1): $52-5$.

142. Shekelle PG, Ortiz E, Rhodes S, et al. Validity of the Agency for Healthcare Research and Quality clinical practice guidelines: how quickly do guidelines become outdated? JAMA. 2001; 286(12): 1461-7. 
143. Transplant Library. http://www.transplantlibrary.com. Accessed November 7, 2017.

144. Umscheid CA. Should guidelines incorporate evidence on patient preferences? J Gen Intern Med. 2009;24(8): 988-90.

145. Rashid A, Thomas V, Shaw T, Leng G. Patient and Public Involvement in the Development of Healthcare Guidance: An Overview of Current Methods and Future Challenges. Patient. 2017; 10(3): 277-282.

146. 147 G-I-N PUBLIC Toolkit: Patient and Public Involvement in Guidelines. http://www.g-i-n.net/document-store/working-groups-documents/g-i-n-public/toolkit/toolkit2015/view. Published August, 2012. Updated October, 2015. Accessed September 20, 2017.

147. Choudhry NK, Stelfox HT, Detsky AS. Relationships between authors of clinical practice guidelines and the pharmaceutical industry. JAMA. 2002; 287(5): 612-7.

148. Graham T, Alderson P, Stokes T. Managing conflicts of interest in the UK National Institute for Health and Care Excellence (NICE) clinical guidelines programme: qualitative study. PLoS One. 2015; 10(3): e0122313.

149. Le Page AK, Jager MM, Kotton CN, Simoons-Smit A, Rawlinson WD. International survey of cytomegalovirus management in solid organ transplantation after the publication of consensus guidelines. Transplantation. 2013 Jun 27;95(12):1455-60. 
150. Hoffmann-Eßer W, Siering U, Neugebauer EAM, Lampert U, Eikermann M. Is there a cut-off for high-quality guidelines? A systematic analysis of current guideline appraisals using the AGREE II instrument. J Clin Epidemiol. 2018; 95: 120-127. 


\section{TABLES}

Table 1: AGREE II Domain Scores and Overall Scores for all CPGs by category

Table 2: Mean compliance to AGREE II items for all CPGs (Range)

\section{FIGURE LEGEND}

Figure 1: Literature flow diagram

Figure 2: AGREE II Domain Scores and Overall Scores for all CPGs 


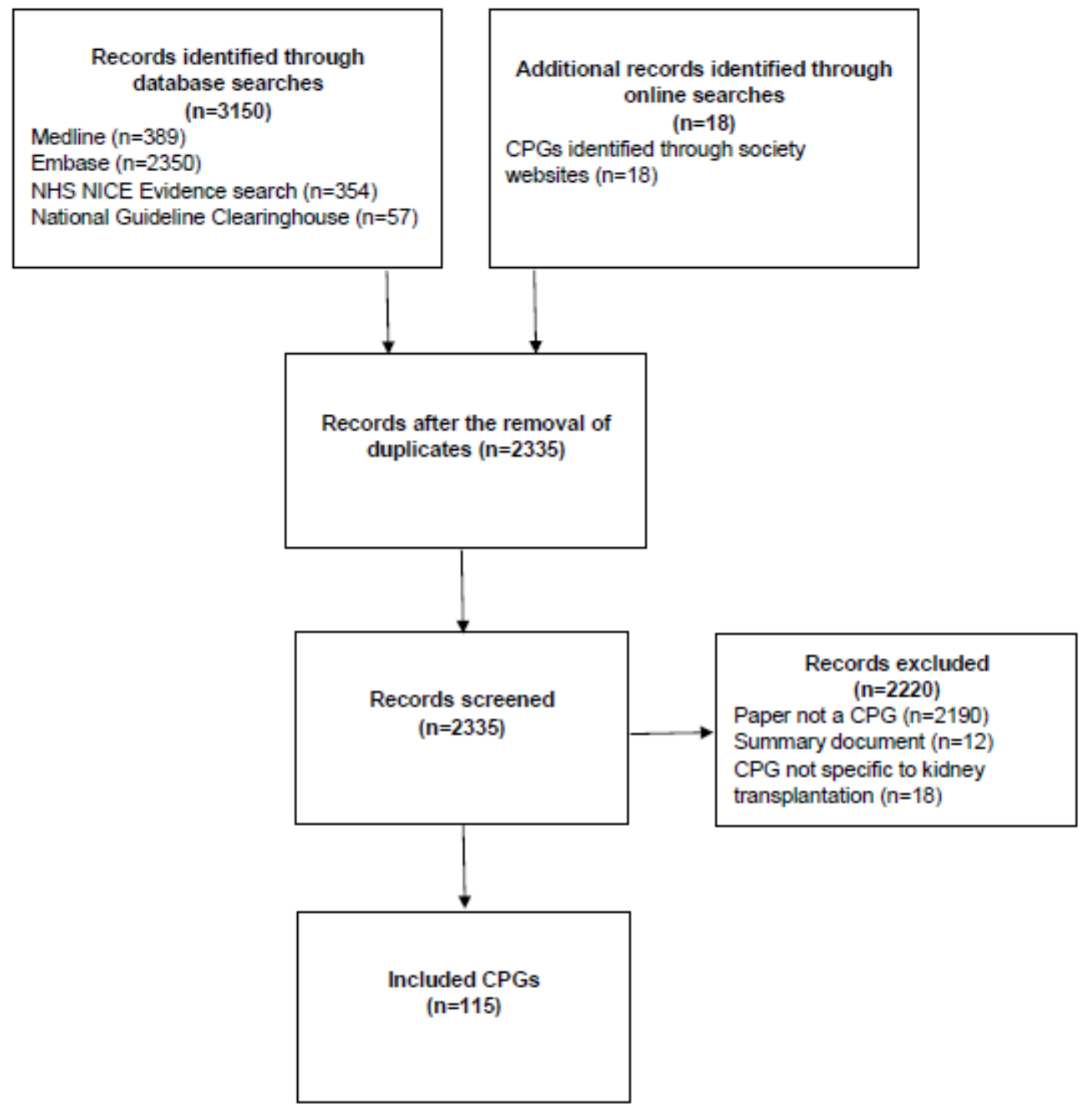

Figure 1: Literature flow diagram 


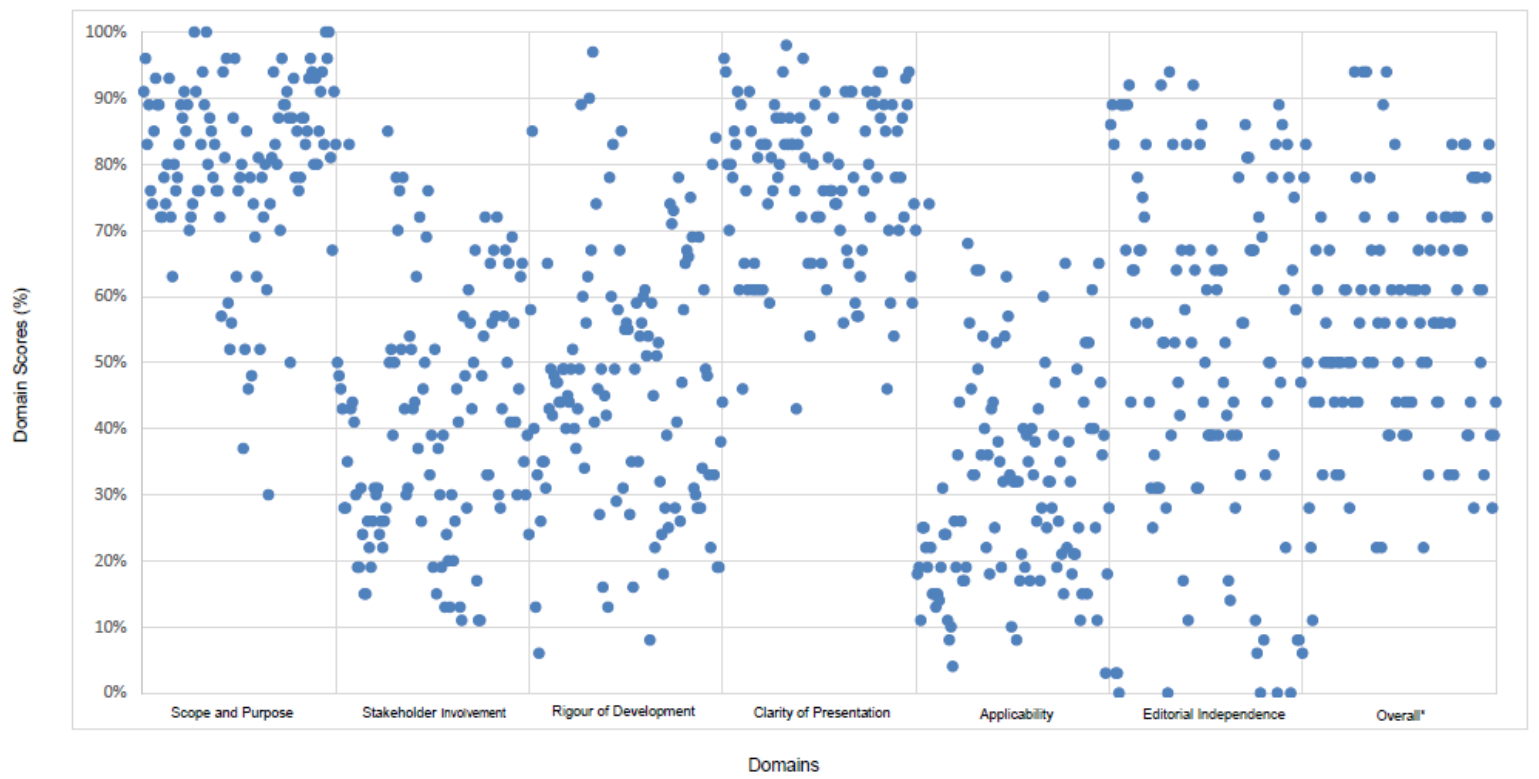

Figure 2: AGREE II Domain Scores and Overall Scores for all CPGs. Each dot within a domain represents a CPG. *Overall scores were converted to percentages using My AGREE PLUS. ${ }^{\circ}$ 
Table 1. AGREE II Domain Scores and Overall Scores for all CPGs by category

\begin{tabular}{|c|c|c|c|c|c|c|c|c|c|c|c|c|}
\hline \multicolumn{13}{|c|}{ Domain } \\
\hline CPGs & Year & $\begin{array}{c}\text { Scope \& } \\
\text { Purpose } \\
(\%)\end{array}$ & $\begin{array}{c}\text { Stakeholder } \\
\text { Involvement } \\
\text { (\%) }\end{array}$ & $\begin{array}{c}\text { Rigour of } \\
\text { Development } \\
\text { (\%) }\end{array}$ & $\begin{array}{c}\text { Clarity of } \\
\text { Presentation } \\
\text { (\%) }\end{array}$ & $\begin{array}{c}\text { Applicability } \\
\text { (\%) }\end{array}$ & $\begin{array}{c}\text { Editorial } \\
\text { Independence } \\
\text { (\%) }\end{array}$ & $\begin{array}{l}\text { Overall } \\
\text { score }\end{array}$ & $\begin{array}{l}\text { Recommended } \\
\text { for future use }\end{array}$ & ICC & Country & Funding \\
\hline \multicolumn{13}{|l|}{ Living donation } \\
\hline $\begin{array}{l}\text { The CARI guidelines. } \\
\text { Potential child-bearing } \\
\text { donors. [10] }\end{array}$ & 2010 & 78 & 19 & 49 & 65 & 15 & 44 & 4 & Yes with Mods & 0.82 & Australia & Not described \\
\hline $\begin{array}{l}\text { The CARI guidelines. } \\
\text { Assessment of donor } \\
\text { kidney anatomy. [11] }\end{array}$ & 2010 & 74 & 19 & 42 & 76 & 14 & 64 & 4 & Yes with Mods & 0.77 & Australia & Not described \\
\hline $\begin{array}{l}\text { The CARI guidelines. } \\
\text { Psychosocial care of } \\
\text { living kidney donors. } \\
\text { [12] }\end{array}$ & 2010 & 80 & 31 & 48 & 61 & 19 & 64 & 4 & Yes with Mods & 0.81 & Australia & Not described \\
\hline $\begin{array}{l}\text { The CARI guidelines. } \\
\text { Justification for living } \\
\text { donor kidney } \\
\text { transplantation. [13] }\end{array}$ & 2010 & 93 & 24 & 47 & 91 & 31 & 56 & 5 & Yes & 0.87 & Australia & Not described \\
\hline $\begin{array}{l}\text { The CARI guidelines. } \\
\text { Donor renal function. } \\
\text { [14] }\end{array}$ & 2010 & 91 & 31 & 49 & 83 & 36 & 31 & 5 & Yes with Mods & 0.81 & Australia & Not described \\
\hline $\begin{array}{l}\text { The CARI guidelines. } \\
\text { Donors at risk: } \\
\text { obesity. [15] }\end{array}$ & 2010 & 85 & 24 & 52 & 83 & 44 & 25 & 5 & Yes with Mods & 0.77 & Australia & Not described \\
\hline $\begin{array}{l}\text { The CARI guidelines. } \\
\text { Donors at risk: } \\
\text { hypertension. [16] }\end{array}$ & 2010 & 89 & 26 & 40 & 74 & 26 & 36 & 4 & Yes with Mods & 0.87 & Australia & Not described \\
\hline $\begin{array}{l}\text { The CARI guidelines. } \\
\text { Donors at risk: } \\
\text { haematuria. [17] }\end{array}$ & 2010 & 70 & 22 & 37 & 59 & 17 & 31 & 3 & No & 0.77 & Australia & Not described \\
\hline $\begin{array}{l}\text { The CARI guidelines. } \\
\text { Donors at risk: } \\
\text { proteinuria. [18] }\end{array}$ & 2010 & 72 & 26 & 43 & 81 & 17 & 31 & 4 & Yes with Mods & 0.85 & Australia & Not described \\
\hline
\end{tabular}


impais a

tolerance. [19]

The CARI guidelines.

2010

living donor

nephrectomy. [20]

Single-port

nephrectomy

Interventional

procedures guidance

[IPG414]. [21]

Living Donor Kidney

2011

85

Edition). [22]

Dynamic challenges

inhibiting optimal

adoption of kidney

paired donation:

findings of a

consensus conference.

[23]

Considerations for

screening live kidney

infections: a viewpoin

on the UNOS policy.

[24]

Living-Donor Kidney

Transplantation:

Reducing Financial

Donation. [25]

Living Donor Kidney

2015

80

56

18

57

Improving Efficiencies

in Live Kidney Donor

Evaluation. [26] 


\begin{tabular}{|c|c|c|c|c|c|c|c|c|c|c|c|c|}
\hline $\begin{array}{l}\text { Living Donor Kidney } \\
\text { Transplantation: } \\
\text { Facilitating Education } \\
\text { about Live Kidney } \\
\text { Donation. [27] }\end{array}$ & 2015 & 87 & 43 & 28 & 57 & 28 & 86 & 4 & Yes with Mods & 0.81 & USA & Non Industry \\
\hline $\begin{array}{l}\text { Living Donor Kidney } \\
\text { Transplantation: } \\
\text { Improving Education } \\
\text { Outside of Transplant } \\
\text { Centers about Live } \\
\text { Donor } \\
\text { Transplantation. [28] }\end{array}$ & 2015 & 70 & 50 & 39 & 63 & 39 & 81 & 4 & Yes with Mods & 0.62 & USA & Non Industry \\
\hline $\begin{array}{l}\text { Consensus conference } \\
\text { on best practices in } \\
\text { live kidney donation: } \\
\text { Recommendations to } \\
\text { optimize education, } \\
\text { access, and care. [29] }\end{array}$ & 2015 & 96 & 67 & 25 & 67 & 47 & 81 & 4 & Yes with Mods & 0.86 & USA & Non Industry \\
\hline $\begin{array}{l}\text { Living Donor Kidney } \\
\text { Transplantation: } \\
\text { Overcoming } \\
\text { Disparities in Live } \\
\text { Kidney Donation in the } \\
\text { US. [30] }\end{array}$ & 2015 & 93 & 65 & 34 & 78 & 53 & 86 & 6 & Yes with Mods & 0.84 & USA & Non Industry \\
\hline $\begin{array}{l}\text { UK Guidelines for } \\
\text { Living Organ Donation } \\
\text { from Prisoners. [31] }\end{array}$ & 2015 & 87 & 48 & 28 & 80 & 21 & 11 & 3 & Yes with Mods & 0.85 & UK & Not described \\
\hline Recipient assessmen & & & & & & & & & & & & \\
\hline $\begin{array}{l}\text { HIV, HBV and HCV } \\
\text { infection. [32] }\end{array}$ & 2011 & 78 & 19 & 56 & 72 & 32 & 61 & 5 & Yes with Mods & 0.58 & Australia & Not described \\
\hline $\begin{array}{l}\text { Paediatric recipient. } \\
\text { [33] }\end{array}$ & 2011 & 46 & 19 & 49 & 81 & 21 & 64 & 4 & Yes with Mods & 0.62 & Australia & Not described \\
\hline Malignancy. [34] & 2011 & 78 & 39 & 59 & 76 & 40 & 61 & 5 & Yes with Mods & 0.57 & Australia & Not described \\
\hline $\begin{array}{l}\text { Cardiovascular } \\
\text { Disease. [35] }\end{array}$ & 2011 & 63 & 13 & 60 & 74 & 17 & 47 & 5 & Yes with Mods & 0.83 & Australia & Not described \\
\hline $\begin{array}{l}\text { Obesity in renal } \\
\text { transplantation. [36] }\end{array}$ & 2011 & 52 & 20 & 51 & 70 & 33 & 42 & 4 & Yes with Mods & 0.62 & Australia & Not described \\
\hline Diabetes Mellitus. [37] & 2011 & 61 & 13 & 45 & 67 & 17 & 44 & 4 & Yes with Mods & 0.79 & Australia & Not described \\
\hline
\end{tabular}


Guideline

assessment of the

potential kidney

transplant recipient.

[38]

Guideline

Clinical Practice

Guideline on

management of

patients with diabetes

and chronic kidney

disease stage $3 \mathrm{~b}$ or

higher (eGFR <45

$\mathrm{mL} / \mathrm{min}$ ). [39]

Criteria for and

in Elderly Patients

With End-Stage Renal

Disease. [40]

\section{Recipient care}

The CARI guidelines.

2010

Donor-specific

transfusions. [41]

Canadian Society of

2010

Transplantation and

Canadian Society of

Nephrology

commentary on the

2009 KDIGO clinical

practice guideline for

the care of kidney

transplant recipients.

[42] 
management

guidelines for the

dental patient with

renal disease and

kidney transplant. Part

1. [43] Routine and

emergency

management

guidelines for the

dental patient with

renal disease and

kidney transplant. Part

2. [44]

KHA-CARI guideline:

KHA-CARI adaptation

of the KDIGO Clinical

Practice Guideline for

the Care of Kidney

Transplant Recipients.

[45]

KDIGO Clinical Practice

Guideline for the

201296

96

76

Management of Blood

Pressure in Chronic

Kidney Disease. [46]

Chronic renal

2012

43

46

dysfunction in kidney

transplant recipients.

Consensus Document.

[47]

ACR Appropriateness

Criteria ${ }^{\circledR}$ Renal

Transplant

Dysfunction. [48]

Diagnosis,

management and

treatment of

glucometabolic

disorders emerging
$2012 \quad 52$

2013
35

26

0.72

Australia

Not described

Industry 
transplantation. [49]

Management of the

Failing Kidney

Transplant. [50]

Solid organ

transplantation from

hepatitis B virus-

positive donors:

consensus guidelines

for recipient

management. [51]

Vitamin $D$ in patients

with chronic kidney

disease. [52]

Vaccination guidelines

in patients with

chronic kidney disease

and renal transplant

recipients travelling

abroad. [53]

Guidelines for

vaccination in kidney

transplant recipients.

[54]

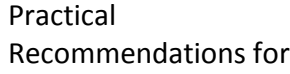

Long-term

Management of

Modifiable Risks in

Kidney and Liver

Transplant Recipients.

[55]

Post-Operative Care in

the Kidney Transplant

Recipient. [56]

Infections
$2014 \quad 78$

2015

87

21

56

80

33

44

5

Yes

0.82

UK

Not described

28

4

No consensus

0.73

USA \&

Canada

Not described

74

18

47

3

No

0.74

Italy

Not described

59

3

8

3

No consensus

0.76

India

Not described

11

0

3

No

0.90

India

Not described

$2017 \quad 94$

67

69

89

53

89

6

Yes

0.86

Europe

Industry 
management of

Mycobacterium

tuberculosis infection

and disease in adult

patients with chronic

kidney disease. [57]

Treatment of

$2011 \quad 76 \quad 39$

55

72

10

cytomegalovirus

disease in renal

transplant recipients.

[58]

Prophylaxis for

Cytomegalovirus

infection in patients

following renal

transplantation. [59]

Diagnostic tests for

Cytomegalovirus in

renal transplantation.

[60]

Preemptive treatment

of Cytomegalovirus.

[61]

GESITRA-SEIMC/REIPI

recommendations for

the management of

cytomegalovirus

infection in solid-

organ transplant

patients. [62]

The Prevention and

2011

2011

81

Australia

Not described

$2011 \quad 74 \quad 24$

Disease after Solid

Organ

Transplantation. [63]

Donor-derived fungal

2012

78

30

27

83

22

Yes with Mods

0.77

Spain

Mixed

infections in organ

transplant recipients.

[64] 


\begin{tabular}{|c|c|c|c|c|c|c|c|c|c|c|c|c|}
\hline $\begin{array}{l}\text { Cytomegalovirus in } \\
\text { solid organ } \\
\text { transplantation. [65] }\end{array}$ & 2013 & 30 & 11 & 22 & 65 & 28 & 28 & 3 & No & 0.80 & USA & Not described \\
\hline $\begin{array}{l}\text { Urinary tract } \\
\text { infections in solid } \\
\text { organ transplantation. } \\
{[66]}\end{array}$ & 2013 & 48 & 13 & 35 & 76 & 19 & 39 & 4 & Yes with Mods & 0.72 & USA & Not described \\
\hline $\begin{array}{l}\text { BK polyomavirus in } \\
\text { solid organ } \\
\text { transplantation. [67] }\end{array}$ & 2013 & 37 & 15 & 27 & 76 & 8 & 39 & 3 & Yes with Mods & 0.81 & USA & Not described \\
\hline $\begin{array}{l}\text { Clinical practice } \\
\text { guidelines for } \\
\text { antimicrobial } \\
\text { prophylaxis in surgery. } \\
\text { [68] }\end{array}$ & 2013 & 87 & 78 & 74 & 87 & 54 & 64 & 6 & Yes with Mods & 0.46 & USA & Non Industry \\
\hline $\begin{array}{l}\text { Consensus document } \\
\text { on the management } \\
\text { of renal disease in } \\
\text { HIV-infected patients. } \\
\text { [69] }\end{array}$ & 2014 & 91 & 50 & 58 & 96 & 18 & 86 & 6 & Yes & 0.88 & Spain & Industry \\
\hline $\begin{array}{l}\text { Clinical practice } \\
\text { guideline for the } \\
\text { management of } \\
\text { chronic kidney disease } \\
\text { in patients infected } \\
\text { with HIV. [70] }\end{array}$ & 2014 & 96 & 48 & 85 & 94 & 19 & 89 & 6 & Yes & 0.90 & USA & Non Industry \\
\hline $\begin{array}{l}\text { Management of } \\
\text { urinary tract infection } \\
\text { in solid organ } \\
\text { transplant recipients. } \\
\text { [71] }\end{array}$ & 2015 & 100 & 65 & 84 & 94 & 36 & 58 & 6 & Yes with Mods & 0.77 & Spain & Not described \\
\hline $\begin{array}{l}\text { Kidney \& Pancreas } \\
\text { Transplantation in } \\
\text { Patients with HIV. } \\
\text { Second Edition. [72] }\end{array}$ & 2015 & 87 & 57 & 66 & 94 & 21 & 50 & 5 & Yes with Mods & 0.81 & UK & Not described \\
\hline $\begin{array}{l}\text { Antimicrobial } \\
\text { prophylaxis for } \\
\text { pneumocystis jiroveci } \\
\text { pneumonia (PCP) after } \\
\text { solid organ } \\
\text { transplantation (SOT). }\end{array}$ & 2015 & 100 & 46 & 80 & 93 & 65 & 64 & 6 & Yes with Mods & 0.80 & USA & Not described \\
\hline
\end{tabular}


Essential Japanese
guidelines for the
prevention of
perioperative
infections in the
urological field: 2015

edition. [74]

\section{Deceased donation}

Guidelines for

tential multiple

organ donors (adult).

Part III: organ-specific

recommendations.

[75]

DTG procurement

201

57

guidelines in heart

beating donors. [76]

Transplantation from

deceased donors after
circulatory death. [77]

How France launched

its donation after

2014

63

33

cardiac death

program. [78]

Spanish consensus

2014

document for

acceptance and

rejection of kidneys

from expanded

criteria donors. [79]

Surgical Technique for

2015

72

46

72

No

0.66

Germany

Not described

Not described

Industry

Abdominal Organ

Procurement. [80] 


\begin{tabular}{|c|c|c|c|c|c|c|c|c|c|c|c|c|}
\hline $\begin{array}{l}\text { Management of the } \\
\text { Potential Organ Donor } \\
\text { in the ICU. [81] }\end{array}$ & 2015 & 91 & 50 & 60 & 87 & 56 & 53 & 6 & Yes & 0.69 & USA & Non Industry \\
\hline $\begin{array}{l}\text { Clinical Guidelines for } \\
\text { Organ Transplantation } \\
\text { from Deceased Donors } \\
\text { Version 1.0. [82] }\end{array}$ & 2016 & 85 & 69 & 49 & 70 & 61 & 22 & 5 & Yes with Mods & 0.51 & $\begin{array}{c}\text { Australia \& } \\
\text { New Zealand }\end{array}$ & Not described \\
\hline $\begin{array}{l}\text { Recommendations for } \\
\text { donation after } \\
\text { circulatory death } \\
\text { kidney transplantation } \\
\text { in Europe. [83] }\end{array}$ & 2016 & 80 & 41 & 61 & 85 & 40 & 61 & 6 & Yes & 0.59 & Europe & No funding \\
\hline \multicolumn{13}{|l|}{ Nutrition } \\
\hline $\begin{array}{l}\text { The CARI guidelines. } \\
\text { Nutritional } \\
\text { management of } \\
\text { dyslipidaemia in adult } \\
\text { kidney transplant } \\
\text { recipients. [84] }\end{array}$ & 2010 & 72 & 15 & 47 & 85 & 24 & 78 & 4 & No consensus & 0.88 & Australia & Non Industry \\
\hline $\begin{array}{l}\text { The CARI guidelines. } \\
\text { Nutritional } \\
\text { management of } \\
\text { hypertension in adult } \\
\text { kidney transplant } \\
\text { recipients. [85] }\end{array}$ & 2010 & 63 & 15 & 44 & 61 & 24 & 67 & 4 & No consensus & 0.78 & Australia & Non Industry \\
\hline $\begin{array}{l}\text { The CARI guidelines. } \\
\text { Nutritional } \\
\text { management of } \\
\text { overweight and } \\
\text { obesity in adult kidney } \\
\text { transplant recipients. } \\
\text { [86] }\end{array}$ & 2010 & 80 & 26 & 44 & 65 & 11 & 67 & 4 & Yes with Mods & 0.83 & Australia & Non Industry \\
\hline $\begin{array}{l}\text { The CARI guidelines. } \\
\text { Nutritional } \\
\text { management of } \\
\text { hypophosphataemia } \\
\text { in adult kidney } \\
\text { transplant recipients. } \\
\text { [87] }\end{array}$ & 2010 & 76 & 22 & 49 & 61 & 8 & 75 & 3 & No & 0.86 & Australia & Non Industry \\
\hline
\end{tabular}


The CARI guidelines.

2010

19

49

81

10

72

interventions for the

prevention of bone

disease in kidney

[88]

The CARI guidelines.

2010

83

26

40

61

management of

anaemia in adult

kidney transplant

recipients. [89]

The CARI guidelines.

$2010 \quad 89$

Nutritional

89

31

45

83

26

management of

diabetes mellitus in

adult kidney

transplant recipients.

[90]

The CARI guidelines.

$\begin{array}{lll}2010 & 87 & 30\end{array}$

Food safety

recommendations for

adult kidney

transplant recipients.

[91]

The CARI guidelines.

26

49

65

in adult kidney

transplant recipients.

[92]

\section{Cardiovascular and lipid complications}

Danish guidelines for

2014

76

lipid-lowering

28

33

80

25

3

2

No

No consensus

0.88

Australia

Non Industry

treatment in patients

with chronic renal

failure. [93]
Non Industry

Non Industry 
management among

kidney and liver

transplantation

candidates. [94]

KDIGO Clinical Practice

Guideline for Lipid

Management in

Chronic Kidney

Disease. [95]

disease:

revascularisation. [96]

Medical management

$2013 \quad 89 \quad 17$

disease (excluding

lipid-lowering

therapy). [97]

Heart Failure. [98]

issues associated with

HLA and non-HLA

antibodies in

transplantation.

Transplantation. [99]

Guidelines for

Transplantation (Third 
therapy for patients

undergoing solid

organ transplantation:

an evidence-based

practice guideline.

[102]

Immunosuppression

Generic

solid organ

transplantation: a

Canadian perspective.

[103]

Advagraf $^{\circledR}$, a once-

release tacrolimus

formulation, in kidney

transplantation:

literature review and

guidelines from a

panel of experts. [104]

Therapeutic Drug

Imaging and biopsies

Imaging

2012

89

paediatric

uroradiology, part V:

childhood cystic

kidney disease,

childhood renal

transplantation and

contrast-enhanced

ultrasonography in

children. [106] 
Tissue pathway for

2013

[G061]. [107]

AIUM practice

2014

89

for the

ultrasound

examination of solid-

organ transplants.

[108]

German

2016

recommendations for

pretransplantation

donor kidney biopsies.

[109]

Standard method for

2016

81

35

ultrasound evaluation

of renal arterial

lesions. [110]

\section{Mixed aspects of transplantation}

ERBP Guideline on the 2013

Management and

Evaluation of the

Kidney Donor and

Recipient. [111]

Guidelines on Renal

Transplantation. [112

52

Kidney donor and

2014

74

recipient

perioperative

evaluation.[113]

Canadian Forum on

2016

93

Transplantation. [114]

Guide to the quality

2016

96

and safety of organs

for transplantation 6th

Edition. [115]
Non Industry
Not described 
Does preemptive

2016

83

30

69

post start of d

transplantation with a

kidney from a living

donor improve

outcomes after

transplantation? A

systematic literature

review and position

statement by the

Descartes Working

Group and ERBP. [116]

\section{Other aspects of transplantation}

Clinical practice

atypical haemolytic

uraemic syndrome in

the United Kingdom.

[117]

Spanish Society of

$2011 \quad 76$

52

recommendations for

controlling mineral

and bone disorder in

chronic kidney disease

patients (S.E.N-M.B.D)

Expert guidelines for

the management of

Alport syndrome and

thin basement

membrane

nephropathy. [119]

Clinical practice

2013

80

52

83

36

management of

chronic kidney

disease-mineral and 


\begin{tabular}{|c|c|c|c|c|c|c|c|c|c|c|c|c|}
\hline $\begin{array}{l}\text { Proposed guidelines } \\
\text { for the diagnosis and } \\
\text { management of } \\
\text { methylmalonic and } \\
\text { propionic acidemia. } \\
\text { [121] }\end{array}$ & 2014 & 89 & 70 & 67 & 83 & 49 & 39 & 5 & Yes with Mods & 0.58 & $\begin{array}{c}\text { Europe \& } \\
\text { USA }\end{array}$ & Non Industry \\
\hline $\begin{array}{l}\text { Consensus statement } \\
\text { on screening, } \\
\text { diagnosis, } \\
\text { classification and } \\
\text { treatment of endemic } \\
\text { (Balkan) nephropathy. } \\
\text { [122] }\end{array}$ & 2014 & 76 & 52 & 34 & 78 & 46 & 53 & 4 & Yes with Mods & 0.69 & International & Non Industry \\
\hline $\begin{array}{l}\text { Guidelines on the } \\
\text { management of } A L \\
\text { amyloidosis. [123] }\end{array}$ & 2015 & 83 & 50 & 63 & 87 & 33 & 0 & 5 & Yes with Mods & 0.80 & UK & Not described \\
\hline $\begin{array}{l}\text { An international } \\
\text { consensus approach } \\
\text { to the management of } \\
\text { atypical hemolytic } \\
\text { uremic syndrome in } \\
\text { children. [124] }\end{array}$ & 2016 & 94 & 28 & 32 & 78 & 25 & 33 & 4 & Yes with Mods & 0.89 & International & Not described \\
\hline $\begin{array}{l}\text { Integrating APOL1 } \\
\text { Gene Variants Into } \\
\text { Renal Transplantation: } \\
\text { Considerations Arising } \\
\text { From the American } \\
\text { Society of } \\
\text { Transplantation Expert } \\
\text { Conference. [125] }\end{array}$ & 2017 & 91 & 56 & 48 & 78 & 40 & 83 & 4 & Yes with Mods & 0.63 & USA & Industry \\
\hline Mean (Range) & & $\begin{array}{c}80(30- \\
100)\end{array}$ & $41(11-85)$ & 47 (6-97) & 77 (43-98) & $31(3-74)$ & $52(0-94)$ & $4(2-7)$ & & $\begin{array}{c}0.74 \\
(0.28- \\
0.92)\end{array}$ & & \\
\hline
\end{tabular}

*Table is based on adjusted scores; Yes with Mods - Yes with modifications; ICC - Intraclass Correlation Coefficient 